\title{
Human Rights Violation: A Study of the Indigenous People of Biafra Agitation (IPOB)
}

\author{
Ifeanyi Kevin*
}

\begin{abstract}
The proliferation of 'violent-oriented' ethnic organizations and agitation groups operating in Nigeria, is a result of the inability of the Nigerian state to resolve the questions of citizenship, resource control, federalism and political representation. This, of course, is an expression of subnationalism and irredentism, hence posing a threat to the survival of the fragile democracy and nation-building in the country. No doubt, the Igbo people who bore the brunt of the Nigerian Civil War has been relegated to the background and are being treated as a minority group in the country, even though they are one of the three major ethnic groups in the country. Another problem is the fact that they have been use as scapegoats in any political crises in Nigeria. They have been extrajudicially killed and their property wantonly destroyed. All these infringed on their fundamental human rights. These factors have fuelled the recurrent agitation therefore Indigenous People of Biafra (IPOB), to protect their rights demanded for a separate state. This study, therefore, concludes that the development of Nigeria will remain a mirage, and Nigeria, making a positive impact in international politics, a white goose chase, should the country fail to tackle her internal political problems.
\end{abstract}

Keywords: Human Right, Violation, IPOB, Agitation

* Spiritan University, Umunneochi, Abia State. Email: ifeanyi.kevin@ccu.edu.ng 
Human Rights Violation: A Study of the Indigenous People of Biafra Agitation (IPOB)

\section{INTRODUCTION}

Ethnic agitation in Nigeria has been and will remain a serious problem in the political history of Nigeria. Nigeria, as an entity, came into existence on January 1, 1914, with the merging of the Protectorates of South and North by Sir Frederick Lugard. This amalgamation has variously been seen as the mistake of 1914, and the unholy wedlock. ${ }^{1}$

There are over two hundred and fifty ethnic groups in Nigeria, which are different in terms of historical and cultural practices. Differences also exist among these groups in their economic ways of life, including the possibility of conflict on religious grounds, especially between the Muslims and the Christians. While this scenario can be seen in other African countries, it is particularly relevant to Nigeria because of its diversity.

The relations between the supposedly 'larger ethnic' nationalities - the Hausa/Fulani, the Yoruba and the Igbo - have been central to the endless power struggle in Nigeria's post-independence politics. The expression of ethno-nationalistic tendencies has attained maximum intensity in contemporary Nigeria, particularly since its return to civilian rule in 1999. In fact, it was in retaliation over the various skirmishes between the Odu'a Peoples' Congress (OPC), founded in 1994, and the Hausa in the Western part of the country, that made Sagir Muhammad, a retired army officer and most of his colleagues, to form the Arewa People's Congress (APC) on December 13, 1999, as an elitist movement which could also act, in extreme cases, as a radical wing of the Arewa Consultative Forum (ACF). ${ }^{2}$ The Organization was set up to protect and safeguard Northern interests against the threat by the OPC and other ethnic groups in any part of the country.

The Movement for the Actualization of the Sovereign State of Biafra (MASSOB) was established in 1999 to fight for the actualizing of the emancipation of Ndigbo and the reestablishment of the Republic of Biafra (ROB). The area envisaged comprises the former Southeastern Region, which includes all the people that occupy the Bight of Biafra. ${ }^{3}$ The Movement for the Emancipation of the Niger Delta (MEND) began in 2006 as an offshoot of the Niger Delta Volunteer Force. It was established to redress the problems in the Niger Delta, as well as to bring the deplorable living conditions of the people in the region to the attention of the federal government. Over the years, the group has engaged in several militia activities like destruction of pipelines, killings and abductions of expatriate oil workers and their own people alike. ${ }^{4}$ The Community Government of Indigenous People of Biafra (CG-IPOB) which led to the birth of the Indigenous People of Biafra (IPOB) was form in 2012 to champion the course of the restoration of the Republic of Biafra.

It should be argued here that these organizations emerged as a result of the return to civilian administration, which created a space for them to operate. It would have been suicidal for them to have operated during the military administration. The example here is the execution of the

1 Innocent Agbu ,The Origin of Biafra (Awka: Mercury Bright Press, 2001) p.2

2 Shola Onimajesin, "The OPC Militancy in Nigeria, 1999-2003: Its Implications and Management." http://www.unilorin.edu.ng/unilorin/publications/onimajesin.html Retrieved October 2020.

3 Ogan Agbu "Ethnic Militias and the Threat to Democracy in Post-Transition Nigeria" News from the Nordic African Institute, Upsala, Sweden. N0.1; January, 2002, Retrieved October, 2020

4 Isaac Adaka-Boro And the Niger Delta Militancy http://www.niaraland.com/nigeria/topic-302497.0html Retrieved October, 2020 
leader of the Ogoni People, Kenule Saro-Wiwa, and seven other Ogoni activists in 1995 by the Gen. Sanni Abacha's military government. ${ }^{5}$

Before the civil war of 1967-1970, the Igbo occupied a strong position in the Nigerian polity and were a group to reckon with. They continued to enjoy this position till the civil war broke out. With the defeat of the Biafrans in the 30 month civil war, the Igbo people lost out and were deprived of their vantage positions in the country. Even Gen. Gowon's principle and philosophy of no victor, no vanquished, which was meant to reassure the international community against further mass killings of Ndigbo was, however, belied by what actually happened on the ground. According to Ahazuem,

the proclamation of the $3 \mathrm{R}$ program of reconstruction, rehabilitation and reconciliation was meant to regenerate hope among Ndigbo and probably make it possible for them to pick up once more, the broken rhythms of their lives. Unfortunately, the $3 \mathrm{R}$ program remained ominously silent on the most important issue of reintegration or the $4^{\text {th }} \mathrm{R}$, on which permanent peace could have been won by the end of the war. The inherent cynicism with which the program was implemented completely vitiated its avowed good intention. ${ }^{6}$

The Igbo people were hemmed in and constricted to a much reduced political space. Even though demographically the Igbo were the largest in population in the former Eastern region, yet by the logic of state creation of the military, the Igbo were reduced to a 'new minority' in the defunct Eastern Region. Today, out of the six geopolitical zones, the Southeast, which is mostly Igbo states, has only 5 states and 74 local governments; while other zones have 6 or 7 states with more than 100 local governments. ${ }^{7}$ In addition, Obi-Ani argues that the Federal Government with its vast resources and diplomatic clout was able to strangulate the seceding State of Biafra through its various economic measures 8 which Ahazuem called "punitive economic measures". 9 According to Obi-Ani, ${ }^{10}$ the Igbo were demoralized through the implementation of Banking Obligation (Eastern States) Degree of 1970 which nullified all pre-war savings that were operated between May 31, 1967 and January 12, 1970, the period Biafra existed as a State. Again, in 1972, the federal government promulgated the Nigerian Enterprises Promotion Decree. This indigenization policy was in principle a bold economic policy that tried to extend the control of the economy to the hands of Nigerians. Ahazuem stated again that,

One important segment of the population, particularly Ndigbo, was not taken into consideration in the implementation of the policy; or was taken into consideration for the wrong reason. And this reason was to consign Ndigbo to the periphery of the Nigerian economy. For one thing, the policy was instituted at a time when they were cash-strapped and did not have the financial strength to participate effectively in the new economic dispensation. This explains why the

5 Ifeanyi Kevin, "Ethnic Militancy in Nigeria: A Case Study of MASSOB, 1999-2010,” Unpublished M.A. Thesis, 2011

6 John Ahazuem, "Post-War Economic Underdevelopment: The Case of Ndigbo and Nigeria” in Onwuka Njoku (Ed) Topics in Igbo Economic History (Ikeja: 1st Academic Publishers, 2008) pp.203-220

7 John "Post-War Economic Underdevelopment, p. 210

8 Paul Obi-Ani, Post-Civil War Political and Economic Reconstruction of Igboland, 1970-1983 (Nsukka: Great AP Express Publishers Ltd, 2009), p109.

9 Op.Cit., John "Post-War Economic Underdevelopment", p.210

10 Op.Cit. Paul , Post-Civil War Political and Economic Reconstruction of Igboland,p.109 
Hausa/Fulani and the Yoruba now dominate the financial and corporate world of Nigeria. $^{11}$

In furtherance of this study, there is need for the clarification of the concepts that guide this study.

\section{Human Rights}

Human rights are those vital privileges, which are enjoyed by all humans everywhere, from birth until death. ... These all-important privileges are based on the following values like equality, fairness, respect, dignity and independence. ${ }^{12}$ Human rights are said to be fundamental because they are natural and very crucial to the development of human beings. They are basic human rights, which every citizen of Nigeria are constitutionally entitled to enjoy for a good development of the human person and the nation. ${ }^{13}$ They are the rights and freedom that is be protected by the constitution of which is recommended by the Government and which is enacted to its citizens. These rights are Right to life, Right to due process of law, Right to freedom of movement, Right to self-determination, Right to liberty, Right to privacy, Right to dignity of human person, Right to freedom of religion, Right to freedom of speech, Right to freedom of movement, etc.

\section{Violation}

Violation is an act of law breaking, principle, agreement, etc. It is also an action which inflicts harm or injury by treating someone or their possessions without respect ${ }^{14}$ Violation can also mean a breach, infringement, or transgression, as of a law, rule, promise, etc. ${ }^{15}$ This entails that every human right in backed by law. It, therefore, behooves on the government to ensure that these rights are not infringed upon. Thus, human right violation can be dehumanizing. This is based on the fact that the survival of man is dependent on the maintenance and defense of his fundamental human rights by the state.

\section{Agitation}

According to Collins Dictionary, agitation is the act of attempting to stir up public opinion for or against something. 16 For Macmillan Dictionary, ${ }^{17}$ agitation is aim at bringing social or political changes through arguments or protests, or other activities etc. For Merriam-Webster Dictionary, it is a determined and continuous attempt to steer up public emotion or stimulate public opinion. ${ }^{18}$ The English Oxford Living Dictionary defines agitation ${ }^{19}$ as the arousing of public concern about an issue and pressing for action on it. Finally, Cambridge Advanced Leaner's

11 Op.Cit., John "Post-War Economic Underdevelopment", p. 213

$12 \mathrm{https}: / / \mathrm{www}$.google.com/search?q=meaning+of+fundamental+human+rights\&oq=meaning+of+fundamental+human+rights\&a qs=chrome..69i57.9607j0j7\&sourceid=chrome\&ie=UTF-8, Retrieved in October, 2020

13 Chapter VI of the 1999 Constitutional of the Federal Republic of Nigeria as amended.

$14 \mathrm{https}: / /$ www.ldoceonline.com/dictionary/violation, Retrieved in October 2020

$15 \mathrm{https}: / / \mathrm{www}$.dictionary.com/browse/violation, Retrieved in October 2020

16 Macmillan Dictionary, https://www.macmillandictionary.com/dictionary/british/agitation, retrieved in October 2020.

17 Merriam-Webster Dictionary, https://www.merriam-webster.com/dictionary/agitation, retrieved in October 2020.

18 Oxford Dictionary, https://en.oxforddictionaries.com/definition/agitation, retrieved in October 2020.

19 Cambridge Dictionary, https://dictionary.cambridge.org/dictionary/english/agitation Retrieved in October 2020. 
Dictionary and Thesaurus define agitation as a condition in which people complain or argue, especially in public, in order to accomplish a particular type of change. ${ }^{20}$ What is to be deduce from here is that, agitation has to do with a demonstration or discussion to bring about a positive change in the society. Thus, agitation can only occur when there are social injustices and anticitizens policies by the government. Hence, agitation occurs to correct anomalies. The perceived marginalization, and other injustices, coupled with the lip-service which the government pays to these anomalies triggered off these agitations.

Many agitators become impetuous and act without bearing in mind the consequences of their actions. In most cases, this could lead to legal action or arrest. Example of this was the arrest of Nnamdi Kanu, self-acclaimed leader of IPOB, and their members; in fact, many are still languishing in jail. The way and manner the federal government of Nigeria is treating the proBiafra agitators, who are clamoring for a change in the society is counterproductive. The nurturing of these centrifugal forces constitutes the veritable basis for recurrent violent conflicts between the state and the ethnic nationalities, thereby affecting the corporate existence of the Nigerian state.

Tekena Tamuno asserts that neither history, nor politics, nor economics have given the cause of federation in Nigeria a smooth ride. ${ }^{21}$ Thus, various ethnic groups began to clamor for the rights and protection of their groups in Nigeria. This, according to Osadolor explains why the nationalist struggles ceased to be an effort to generate national consciousness for nation building, and became a movement to reconcile conflicting aspirations of the political class at the level of inter-ethnic, inter-regional and inter-party relations. ${ }^{22}$

Aggressive behaviors of agitators are often a source of frustration for people who agree with their course, but do not support extremism, because radicalism can give an active movement a bad name. Agitators are often led by charismatic leaders who demand absolute loyalty and cohesiveness in their group. In some cases, agitators are treated as terrorists who undermine safety and security. It is on this assumption that the security agents of the federal government of Nigeria massacred members of IPOB at the National High School, Aba, Abia State, and other places in the Southeast during their prayer sessions and other activities. ${ }^{23}$

Isiaka sees ethnic agitation as an ethnically organized group whose sole aim is to champion the course and sectional interest of their ethnic group, and whose activities sometimes involve the use of violence ${ }^{24}$ or verbal aggression. Ethnic agitation is also seen as an extreme form of ethnic nationalism or irredentism geared towards self-determination. This happens when an ethnic group assumes an aggressive posture, which could be either violent or non-violent, and gradually metamorphoses into a militant group, which bears an ethnocentric coloration and purports to act as a channel that could help the people realize their desires. ${ }^{25}$ Major

20 Dictionary of Etimology,https://www.etymonline.com/search?q=translate+agitator+to+latin and Latin Dictionary, https://latindictionary.net/definition/2306/agitator-agitatoris Retrieved in October 2020.

21 Tekena Tamuno, "Nigerian Federalism in Historical Perspective" in Kenneth. Amuno (ed) Federalism and Political Restructuring in Nigeria, (Ibadan: Spectrum Books Ltd., 1998) p.13

22 Ben Osadolor, "The Development of the Federal Idea and Federal Framework, 1914-1960" cited by Onwuka Njoku, "From Ethnic Consciousness to Ethnic Nationalism: The Nigerian Example"

23 Chidindu Kanu, Chinweike Okoro, Jude Njoku and Calistus Elemuo (Oral Interview)

24 Badmus Isiaka, "Ethnic Militia Movements and the Crisis of Political Order in Post-Military Nigeria" p.20

25 Mamedu Akintunde, 'Can the Centre Hold?' Africa Today, (6) 2: 2000 p.39 
characteristics of these parochially stimulated groups are the recourse to aggression or nonviolence, youth membership, ethnic consciousness, and the demand for change of the status quo.

From the foregoing, it can be deduced that it is when an ethnic group begins to use violence and recourse to arms to protect and promote its parochial interest that such a group could be seen as violent ethnic agitation group. However, IPOB could be seen as a verbal aggressive group because of its use of hate speeches and foul languages, both by the leadership of the organization and its members, albeit without recourse to arms. The group amplifies her struggle using the media; and believes that non-violence remains their official principle. This, however, remains doubtful owing to the verbal vituperation which the leadership of the group and its members are known for. This stance is somehow doubtful because even though the members don't carry arms, they are quite aggressive to anybody that is against the IPOB, whether Igbo or otherwise. In fact, one of the charges against Kanu when he was arrested in October 2015, was a treasonable felony for a speech he delivered at a World Congress of Ndigbo held in 2015, where he asked the people for weapons to fight war for Biafra. ${ }^{26}$ Nevertheless, the perceptions of marginalization, exclusionary politics, cumulative injustice, a weak economy, politics of hatred, ethno-religious killings, as well as state coordinated repression are factors that strengthen the neo-Biafra agitation. ${ }^{27}$ The major reasons that led to the emergence of MASSOB, undoubtedly led to the emergence of IPOB; and each of them is concerned with the various injustices and the relegation of the Ndigbo to the background by the government of Nigeria. As is already established, after the defeat of Biafra in the Civil War of 1967-1970, there appeared to be a period of wellcoordinated and organized reparations meted against Ndigbo. ${ }^{28}$ The Biafrans, especially Ndigbo, became scapegoats in any political crises in Nigeria. Between 1970 and 1999 the Igbo suffered untold hardship, marginalization and deprivation, all of which stirred up ethnic nationalism among the people. The maltreatments, in question, cut across all spheres of life.

\section{Modes of Operation of IPOB}

The ideology that drives IPOB was the passion for freedom, which was the most repeated explanation of the members of the organizations. They were of the opinion that the current structure of Nigeria does not allow them to express themselves freely and to maximize their potential fully. This made Oloyede, ${ }^{29}$ to assert that the members of the group see Biafra as not only their birthright, but as the only means of regaining their lost freedom. He went on to say that,

The feeling of being in "bondage" in Nigeria is an idea that emerged from the post-war realities. Of course, any vanquished in a duel is most likely to assume such disposition, especially when the victor either through overt or covert means

26 Ekene Egbujule, and Onyinye Anyadike, "Nigeria fails to come to grips with separatist" New Biafra, 16 December 2016 , https://www.refworld.org/docid/585a4f2c4.html Retrieved in October 2020.

27 Idachaba, E.U. and Nneli, T.J. "Re-Invented Abroad: Agitation for Self-Determination. p.30

28 Christian Opata, "Radical Ethnic Organizations and the Sustenance of Democracy: The Case of MASSOB" in Juluis Onuoha and Paul Okpoko (eds) Ethnic Nationalism and Democratic Consolidation: Perspectives from Nigeria and the United States of America (Nsukka: Great AP Express Publishers Ltd., 2004), p.222

29 Oyedele Oloyede, "Biafra in the Present: Trauma of a Loss" African Sociological Review/Revue Africaine de Sociologie, 13(1), 2009, pp. 2-25. 
suggests this. The militarization of the Igbo public space further strengthens this mind-set and makes the agitators feel that the only way that they can be free to express themselves the way they want is through self-rule. ${ }^{30}$

In summarizing the reasons for their agitations, the pro-Biafra groups said that,

The non-violence approach for the Biafra restoration is a revolution against the persistent negligence, political marginalization and structural imbalance against Ndigbo by various Nigerian governments since 1970. We are in this selfactualization struggle because of political, economic, academical (sic) religious slavery, which the government of Nigeria subjected Ndigbo to in Nigeria. We are in this to counter and redress the evil plan to enslave our children and their future, we are in the struggle to restore and revive the doggedness, economic independency (sic) and industrial nature of Ndigbo. Truly, we are in the struggle to restore the dignity, culture and honor of Ndigbo. ${ }^{31}$

The above argument was supported by the International Crisis Group. According to this group, the actions of the pro-Biafra movements, are aimed at attracting the interest and presence of the federal government to the region... centered on the long standing and current socio-political and economic grievances." 32 However, the IPOB believes that the principle that guides their strategy of engagement and pursuing their ambition is "non-violent and civil disobedience." Thus, some informants told the present researcher that they make sure they are non-violent even when attacked. They do not retaliate when they are shot at. Their retaliation would have given the security operatives the opportunity to call them rebels and use that opportunity to kill them. "Our strength lies in the fact that we don't retaliate, we just remain resolute. This is what makes us relevant. Our leaders always tell us... Do not go with any arms...just go with your flags. Don't destroy anybody's property. We operate a command and control system, thus we obey our leaders to the latter.",33

The major tool of IPOB's engagement is the media, both electronic (radio) and social media. While the radio is key in promoting group-cohesion as member's tune in at designated times as directed by their leaders. The social media has also been identified as one of their most potent tools of engaging the public. Thus, for all their events, members are encouraged to record videos and pictures and subsequently post them on social media platforms. Such means are also used to attract membership. The leadership of the IPOB recognizes this fact and even makes an effort to provide free $\mathrm{Wi}-\mathrm{Fi}$ feed for all members on days during which they plan to hold rallies or protests. They often do this in anticipation of mobile network shut down by the Nigerian government on such days. ${ }^{34}$ Though the IPOB are physically non-violent, the capacity of the

30 Op.Cit., Oyedele "Biafra in the Present: Trauma of a Loss" p.6

31 Charles Oji "Biafra Agitators Kick Against Igbo Leaders Decision" The Nation, July 3, 2017, p.8

32 International Crisis Group, Nigeria: The Indigenous People of Biafra (IPOB), including Objectives, Structure, Activities, Relations with other Biafran Independence Groups, and Treatment by Authorities (2014-October, 2016) https://www.refworld.org/docid/5844003b4.html Retrieved in October 2020.

33 Chijioke Kalu , Epele Biepi and Tamunosiki Dere (Oral Interview)

34 Salihu Opejobi, "Biafra: IPOB Denies Taking up Arms against Security Agencies in Self-defence," Daily Post, 2017. http://dailypost.ng/2016/02/17/biafra-ipob-deniestaking-up-arms-against-security-agencies-in-self-defence/ Retrieved in October 2020. 
media, which has become their major tool of engagement to incite violence through hate speech, remains undisputed. As a result of these hate speeches, the broadcasting authority in Nigeria, tried severally, though without success, to block or prevent the broadcasting of Radio Biafra in her air space.

The current pro-Biafra agitation is an act of self-preservation occasioned by the manner citizens of Eastern region are being treated and the attitude of the federal government towards them. Supporting the views of the agitators, Dahiru, cited by Amamkpa and Mbakwe, argues that,

The resurgence of the Biafra agitation...is as a result of the intensified marginalization of Ndigbo under Muhammadu Buhari's administration. Buhari's political strangulation tactic of $97 \%$ and $5 \%$ support and delivery formula directly proportional to the number of the vote cast for him is made factual and Ndigbo seem to be penalized for exercising their democratic choice, as enshrined into the constitution. ${ }^{35}$

All the informed the current nationalistic agitations of the pro-Biafra groups championed by IPOB.

\section{Reactions of the Nigerian Government to the Activities of the IPOB}

It is germane to state here that the various activities of the IPOB, especially between 2015 and 2017 were quite significant in the agitations of the group. This is because it was in 2015 that the leader of the group, Nnamdi Kanu, was arrested, while 2017 was when he was released. During this period, IPOB was at the height of its activities. The "threat" their activities posed to the federal government and other segments of the society led to clamp down on members of the group. It also resulted to a quit notice given to Ndibo resident in the North, and the subsequent proscription of the group by the federal government. ${ }^{36}$

The activities of the IPOB prior to the 2015 general elections were largely benign, concentrating on casting aspersions and verbal vituperations against real and imagined enemies of Biafra, until later that year (2015) when their leader, Nnamdi Kanu was arrested. The group's intensified agitation from all indications, amongst others, is not unconnected with the realities of political development which assumed tense climate towards the second half of 2015. Buhariphobia, as a result of the emergence of Buhari after the election, could be one of the major triggering factors. This is because Muhammadu Buhari, since his days as the military ruler and after, has been on a loggerhead with Ndigbo. In fact, Gen. Muhammadu Buhari was reported to have brazenly aired on BBC Hausa in January 2015, that he is been hated by Ndigbo as a result of his brutality during the Biafran War. He said that he has no regret, and owe Ndigbo no apology; and that should another civil war occur, he would kill more Igbo people to keep Nigeria safe. ${ }^{37}$

35 Amamkpa, A. and Mbakwe, P. “Conflict Early Warning Signs and Nigerian Government Response Dilemma”,p.25

36 Sola Ojo, Timothy Olanrewaju, Gorge Onyejiuwa and Chinelo Obogo, "Quit Notice Order to Igbo: IGP Reads Riot Acts", Daily Sun, June 9, 2017;Godwin Tsa, Aloysius Attah, and Laide Raheem” IPOB Remins Terrorist Group”, Daily Sun, 26 September, 2017

37 Ekpo, C.E. and Agorye, C.A. "A (un) Just and (un) Holy War? The Theme of Imagery and Symbolism in the IPOB Secessionist Struggle” in International Journal in Management and Social Science Volume 6 Issue 06, June 2018, pp.38-46 
With the loss of election in 2015 by Goodluck Jonathan to Muhammadu Buhari, the pro-Biafra agitation became highly virulent. Expectedly, the government aggressively reacted to this by arresting Nnamdi Kanu, the leader of the group, and some members of his movement for acts of terrorism and treasonable felony. The subsequent protests for the release of Kanu across the Southeast and South-south Regions and elsewhere turned bloody as many members of the group, not fewer than 40 people, including a soldier, were reportedly killed and many were arrested. ${ }^{38}$ With the national and international reactions against Nnamdi Kanu's 'unlawful' detention, it was expected that the democratically elected Government of Muhammadu Buhari would have released him early enough, and try to investigate the root-cause of the resurgence in the demands of the pro-Biafra group. It was the failure of the federal government to release an unarmed nonviolent political agitator that resulted in a series of demonstrations world over, especially in Nigeria. This led to shooting and killing of about ten innocent civilians and wounding of many more on December 2, 2015. ${ }^{39}$ Although justified on the grounds of sedition charges, the arrest of Mr. Kanu by the federal government has been adjudged by many as a major strategic blunder in the Nigerian government's conflict early warning and early response system. ${ }^{40}$

The gruesome murder of those innocent, unarmed citizens is, indeed, a crime against humanity. No one else but the Nigerian government and her agents and security forces are to be held accountable for this avoidable crime. There have since been intermittent and indeed internecine clashes resulting in several casualties and gory scenes. Also, the agitations became more frequent and more lethal. During the clashes that erupted in 2016 between the pro-Biafra agitators and the security forces, more than 146 members of the group were killed. These were as follows, 9 deaths in Delta (Delta State), 61 in Aba (Abia State) and 76 in Onitsha (Anambra Stat), Abia (61 deaths). In addition, during the Biafra remembrance day of May 30, 2016, the security forces clashed with the members of the pro-Biafra group in the Onitsha/Nkpor axis of Anambra State, killing between 32 and 95 Biafra agitators. ${ }^{41}$ Prior to this period, the activities of IPOB were at a non-violent stage, limited only to anti-government propaganda. But with the government's clampdown on IPOB, the group's resistance came to be identified with a leading figure, Kanu, who was being designated or eulogized as the "liberator of the Igbo," "the Igbo messiah," and "the conqueror of the zoo republic" etc. The clamp down also attracted international attention to the movement. Thus, several calls were made for the release of Kanu from across the globe, especially from human right groups, and even from some superpowers in the international community. The pro-Biafra agitation also garnered significant CNN effect, while some scholars, both local and foreign argue that the Igbo have a right, under international law, to selfdetermination. $^{42}$

On May 5, 2017, just a few weeks after his bail, the IPOB leader, through the Publicity Secretary of the group, Emma Powerful, asked their members to stay at home as a mark of honor to their fallen heroes.. This is in commemoration of the 50th Anniversary of the defunct Republic of Biafra. According to him,

38 Innocent Ojibara, "Biafra: Why Igbo Want to Secede" in Arabian Journal of Business and Management Review (Nigerian Chapter) Vol. 4, No. 1, 2016, pp. 53-61

39 The Alaigbo Development Foundation (ADF) CONDEMNS. p.46.

40 Op.Cit. Ekpo, C.E. and Agorye, C.A. "A (Un) Just and (Un) Holy War?”

41 Op.Cit. Amamkpa, A. and Mbakwe, P. "Conflict Early Warning Signs and Nigerian Government Response Dilemma..."

42 Thompson Okonkwo, and Godwin Kingston "An Assessment of the Rights of the IPOB to Self-determination under International Law”, Sacha Journal of Human Rights, Vol. 16(1), 2016, pp.99-110, and Emeka Emekesiri, Biafra or Nigerian Presidency: What do Igbos Want? pp. 269-274. 
We call on all Biafran to sit at home to evade falling victims. We don't want to lose any soul. If you stay at home, they cannot come to your house and bring you out, we warn you... The Biafra Day Remembrance of this $30^{\text {th }}$ May [2017] and Sit-at-Home Order is to notify the Nigerian Government and her security agencies, Nigerians, and indeed the entire world, that this set of Biafra generation means business. ${ }^{43}$

This sit-at-home order was later extended to other areas outside the Biafraland to include all places where Biafra people reside, like Kano, Kaduna, Jos, Markudi, Ibadan, Lokoja, Jigawa, Jalingo, Mubi, Yola, Lafia etc. According to the Publicity Secretary of the IPOB, the sit-at-home would be monitored by the international observers, after which the struggle for Biafra freedom would move to another level. ${ }^{44}$ The successes recorded by this sit-at-home order was such that it led to a series of clampdown of the members of the group by the security operatives as well as the quit notice order to Ndigbo living in the Northern parts of the country. ${ }^{45}$ This quit notice tagged "Kaduna Declaration" read by Mallam Abdulazeez Suleiman, from the Arewa House Kaduna concluded that,

henceforth, as this proclamation is being made and signed, we hereby affirm that we will no longer coexist with the Igbos and shall take definite steps to end this union by removing the North from this present federal construct...we, therefore, notify the Nigeria authorities and the entire nation, that come October 1, 2017, we shall begin the execution of clear activities to show to the entire world that we shall no longer join any federal arrangement with the Igbos...From the date of this pronouncement, which is Tuesday, June 6, 2017, all Igbos presently residing in any part of Northern Nigeria are hereby served notice to quit within three months, and all northerners residing in the East are advised likewise. $^{46}$

This quit notice generated serious action and reaction from within and outside the country. The Nigerian government was called to see a way of wading into the problem by preventing another civil war or slaughter of Ndigbo living in the North. In fact, the Ohanaeze Youth Council (OYC) reacted immediately by saying that with the over 44 Trillion investment in the North, Igbo people are not going anyway. They should be ready to defend themselves in the event of any provocation and attack.

To avoid some altercations and any form of public disturbances, the Governor of Kaduna State, ordered the apprehension and interrogation of the signatories to that pronouncement, and investigate every situations, as well as the all the persons implicated in the matter. ${ }^{47}$ In the same vein, the Inspector General of Police, Ibrahim Idris, gave order to all the Commissioners of Police in the North to arrest and prosecute the instigators of the declaration or have themselves to

43 Ugoji Eke “IPOB Asks Members to Stay at Home on Remembrance Day,” The Nation, May 10, 2017, p. 43

44 Julius Agbodo, Amara Attah, and Patience Obi, “Biafra Day: IPOB Extends Sit-at-Home Order, ” Daily Sun, May 25, 2017, p. 10

45 Naomi Onu, Calistus Oji, Chinelo, and Samuel Nwankwo, "Biafra Day Grounds Imo, Enugu, Anambra and Abia", The Nation, May 31, 2017, p.1, and Sun Reporters, "Biafra: South-East Shuts Down”, Daily Sun, p.10

46 Samuel Ojo, and Monday Kilete, "North Declares War on Igbo", Daily Sun, July 7, 2017, p 6

47 Samuel Ojo, Timothy Olanrewaju, Godwin Onyjiuwa, and Chinedu Obogo "Quit Order: Igbo Spit Fire," 
JHSS, Vol. 11, No. 2, July to December, 2020

blame. ${ }^{48}$ Unfortunately, all these were smokescreen because no single action was carry out nor the perpetrators arrested. This tries to support the argument that some people are treated as 'untouchables or sacred cows.

\section{Violation of the Rights of the Indigenous People of Biafra}

We shall approach this by looking at the various international conventions and statuses that qualify and guarantee the quest for self-determination. The reason for this is to find out if there is any justification, at all, for the activities of the pro-Biafra Groups, especially with the gross abuse of the basic privileges of the members of the group and other members of the Igbo ethnic nationality. First of all, we shall define the concept of self-determination as it relates to the struggle for self-determination and secession by the various pro-Biafra groups. The idea of selfdetermination was first made by Woodrow Wilson, former US President, in January 1918. He said that self-determination is not an ordinary expression. It is a very crucial code of action that leaders and policymakers will from henceforth disregard at their own jeopardy. ${ }^{49}$ The Universal Declaration of Human Rights of December 10, 1948, provides that "the will of the people shall be the basis of the authority of government." This social contract behooves on the government to remain responsible and accountable to the people to whom the government belongs to. Selfdetermination is essentially the legitimate privilege of citizens to control their own lives. This helps the citizens to select their own form of economic, cultural and social development, and also determine their political future. According to the Unrepresented Nations and Peoples Organization (UNPO),

Exercise of fundamental human right can result to political independence, as well as full integration within a state. The significance of this is on the freedom of choice, and the outcome of this must not upset or inhibit the actuality of the right to choose. In reality, a likely consequence of an application of selfdetermination, in most situations, define the intention of governments towards the actual claim by a people or nation. Cultural autonomy may be accepted by a state, but claims to independence will be rejected and opposed vehemently. The privileges of self-determination are, nevertheless, documented in international law as an inalienable right belonging to peoples and not to states or governments. ${ }^{50}$

Self-determination is documented as a privilege of all humans in the first article common to the International Covenant on Civil and Political Rights and the International Covenant on Economic, Social and Cultural Rights, both became enforceable in 1976. In Paragraph 1, the Article provides that: the right to self-determination should be enjoyed by all the peoples, and by this, they are free to control their political destiny and pursue their, social, cultural and economic developments. ${ }^{51}$ Self-determination, as a right, is documented in many international and regional instruments.

48 “Quit Order to Igbo: IGP Reads Riot Act,” Daily Sun, June 9, 2017, p. 6

49 Wolfgang, D. Anne-Marie Gardner https://pesd.princeton.edu/ Retrieved in October 2020.

50 Ibid.,

51 The Unrepresented Nations and Peoples Organization (UNPO) Retrieved in October 2020. 
The UN's Resolution 61/295 of 2007 recognized the right to self-determination of the indigenous peoples. $^{52}$ In addition, the African Charter on Human and Peoples' Rights (ACHPR) has been domesticated and engraft by the Nigerian government by enacting the African Charter on Human and Peoples' Rights (Ratification and Enforcement) Acts, Cap 10 Laws of the Federation of Nigeria1990, thereby making the law enforceable in Nigeria. Article 20 (1-3) of the ACHPR states as follows,

1. All peoples shall have the right to existence. They shall have the unquestionable and inalienable right to self-determination. They shall freely determine their political status and shall pursue their economic and social development to the policy they have freely chosen.

2. Colonized or oppressed people shall have the right to free themselves from the bond of domination by resorting to any means recognized by the international community.

3. All peoples shall have the right to the assistance of the state parties to the present Charter in their liberation struggle against foreign domination, be it political, economic and cultural. $^{53}$

It is imperative to state here that this article lays a legal foundation and justifies the Biafran struggle as championed by the pro-Biafra groups. It guarantees the unquestionable and inalienable rights of the remnants of Biafra-those who survived the civil war-to selfactualization; the freedom to adopt their political standing and follow their economic and social development. Article 20 (2), shows that people who are under colonial rule or being oppressed have the right to loose themselves from the bonds of domination. Here, Okonkwo and Kingston, ${ }^{54}$ argue that this statement only concerns states under colonial rule and such has nothing to do with the self-determination championed by the IPOB. This was disputed by Emekesiri that if lawyers argue that Biafrans are not colonized people, they cannot argue that Biafrans are not oppressed. ${ }^{55}$ The oppressions faced by the Biafrans, especially Ndigbo, since 1970, leave much to be desired. Some of these have been examined in previous chapters. However, Article 20 (3) of the ACHPR mandated all states that are signatories to that Charter, including Nigeria, to assist oppressed peoples in their liberation struggles. This is a serious indictment on the government of African countries that have failed to recognize the rights of proBiafra groups; especially Nigeria that has proscribed the activities of the groups, ignoring the ACHPR that she has domesticated.

Additionally, the Customary International Law is one of the prominent sources of International Human Rights Law. For instance, the provisions of the International Court of Justice (ICJ), Article 38(1) (b), posits that the ICJ shall apply, 'International convention as proof of a general practice accepted as law.' Also, the Reaffirmation of the Law, 3rd Restatement of the United States Foreign Relation Law,1.1 for example, maintain that 'a state violates international law if as a matter of state policy, it practices encourage or condone... genocides, slavery, murder, and other heartless behaviors, protracted and indiscriminate incarceration, racial discrimination or gross violations of international recognized human rights. Appropriate remedies for any violation of human rights obligations are provided for in the said law. A clear judicial pronouncement is

52 Op.Cit. Emeka Biafra or Nigerian Presidency, p.271

53 Ibid.

54 Op.Cit. Thomson and Godwin "An Assessment of IPOB”, p. 105

55 Op.Cit. Emeka Biafra or Nigerian Presidency, pp.273-274 
found in the United States case of Filar tiga v. Pena-Irala, where it was established that 'an act of torture committed by a state official against the one held in detention violates established norms of the international law of human rights and hence the law of nations... ${ }^{56}$ It is pertinent to state at this point that there is no limitation to the issues that are accommodated under the customary international law of human rights, as a result of the affairs of men.

The African Charter on Human and People's Rights was adopted in 1981 by the Meeting of the African Heads of States and Governments of the Organization of African Unity, and came into force on October 2, 1986. This Charter has been domesticated by almost, if not all African countries, Nigeria inclusive, and it guarantees the protection of human rights of the citizens of the member states. This Charter covers a wide range of rights, which includes cultural, social, economic and sundry people's rights to self-determination, development and a general satisfactory environment. ${ }^{57}$ As a major actor in the affairs of the continent, Nigerian government should understand that fundamental human rights, and especially, the right to self-determination, is now a universally acknowledged right that is entitled to and available to all, be it the proBiafra groups or any other aggrieved indigenous peoples. In fact, Chapter IV of the 1999 Constitution of Nigeria, as amended, tends to contain many items about the fundamental human rights of the citizens. ${ }^{58}$

Thus, in reaction to self-determination in the Nigerian 1999 Constitution as amended, Brown and Brown argue that sections 35 to 42 contain various rights to citizens of Nigeria. For example, Section 33 deals with right to life, while section 34 deals with right to dignity of human person. Section 35 deals with right to personal liberty; Section 36 deals with right to fair hearing; Section 37 deals with right to private and family life; Section 38 deals with right to freedom of thought, conscience and religion; Section 39 deals with right to freedom of expression and the press; Section 40 deals with right to peaceful assembly and association; Section 41 deals with right to freedom of movement; and Section 42 deals with right to freedom from discrimination. These rights are inherently vested in Nigerian citizens by the Nigerian government and enshrined in the 1999 Constitution (as amended). These rights are known as "rights to self-determination." ${ }^{59}$ This military imposed constitution, which vowed to promote freedom, equity and justice, became onesided such that the interests of all the Nigerian were not taken care of. In fact, it was the parochial politics played at the centre that led to the Civil War of 1967-1970. According to Prof. Ben Nwabueze, the secession movements at the time were as follow,

1. the indisposition or incapability of the government to defend the Igbo and their belongings from acts of wanton destruction;

2. there was fear and insecurity among the Easterners;

3. the lack of trust in the agreement reached between Gen. Yakubu Gowon and Col. Chukwuemeka Odumegwu Ojukwu at Aburi, Ghana, concerning the form of government for Nigeria; and

56 Amuda Kannike "Agitation for Independent State of Biafra and its Implications under Domestic and International Human Rights Laws” p.38

57 Ibid.,

58 Constitution of the Federal Republic of Nigeria, 1999, as Amended.

59 Michael Brown, and Margret Brown, "Are There Politico-Legal Differences between Self Determination and Secession: A Comparative Analysis on the Nigeria and Biafra Civil War 1967-1970" in International Journal of Public Policy and Administrative Studies, 11(4): January, 2018, pp. 1-4 


\section{Other acts of persecution against Ndigbo. ${ }^{60}$}

It was as a result fn the above that then Lt Col. Chukwuemeka Odumegwu-Ojukwu, in the following statement declared the Eastern Region as an Independent Nation. In his words,

you the people of Eastern Nigeria conscious of the supreme authority of Almighty God over all mankind... aware that you can no longer be protected on your property by any government outside (the Eastern Region Government)... affirming your trust and confidence in me, having mandated me to proclaim on your behalf and in your name that the Eastern Nigeria become a sovereign and independent republic. ${ }^{61}$

The above resulted into a 30-month civil war. At the end of the war, the federal military government of Nigeria declared the war "no victor, no vanquished" and introduced the Three Rs (3Rs) policy of Reconstruction, Rehabilitation and Reconciliation which was aimed at bringing the defeated Ndigbo back to Nigeria. But according to Ahazuem,

The proclamation of the 3Rs programme of Reconciliation, Rehabilitation and Reconstruction was meant to regenerate hope among Ndigbo and probably make it possible for them to pick up, once more, the broken rhythms of their lives. Unfortunately, the 3R programme remained ominously silent on the most important issue of 'Reintegration' or the $4^{\text {th }} \mathrm{R}$, on which permanent peace could have been won by the end of the war. The inherent cynicism with which the programme was implemented completely vitiated its avowed good intentions. ${ }^{62}$

The federal government with its vast resources and diplomatic influence was able to strangulate the seceding State of Biafra through its various economic measures, which Ahazuem called "punitive economic measures". 63

\section{CONCLUSION}

It will amount to unnecessary repetition to go into the various reasons that led to the agitation for self-determination by the IPOB. However, each of them is not unconnected with the various injustices and the relegation of the Igbo people to the background by the successive government of Nigeria. Between 1970 and 2017, Ndigbo have suffered untold hardship, marginalization and deprivation and extra judicial killings, all of which stirred up ethnic nationalism among the people. The maltreatments, in question, cut across all spheres of life. Thus, the agitations for a sovereign state are informed by this ugly trend. The pro-Biafra groups, especially the IPOB, are determined to redeem the Igbo and restore their self-confidence. It is an irredentist movement aimed at breaking away from the subtle but vicious modern day Nigerian enslavement of the Igbo. Hence, Ojukwu said,the Ndigbo have more reason than ever to seek independence. What

60 Nwabueze, B. A. Constitutionalism, p.261; and Olaniyi Oladejo, 'The Illusion of Revolutionary Idealism', The Guardian, Thursday October 17, 1991, p.15

61 Ijalaye, 'Legal Implications of Nigerian Civil War', AJNH, 1969, pp.70-78

62 John "Post-War Economic Underdevelopment, 215

63 Ibid., 
JHSS, Vol. 11, No. 2, July to December, 2020

upsets the Igbo population is, we are not equally Nigerians as the others and as such separation becomes an attractive option. ${ }^{64}$

In addition, Chinua Achebe said that

\begin{abstract}
All the ethnic nationalities in Nigeria have one thing in common, and that is the resentment of the Igbo... The history of modern Nigerian has been marked by intermittent outbursts of anti-Igbo feeling of more or less serious import; but it was not until 1966-7 when it swept through Northern Nigeria like "a flood of deadly hate" that the Igbo first questioned the concept of Nigeria. ${ }^{65}$
\end{abstract}

This problem has continued to reverberate in the contemporary Nigeria, making the current Igbo youths to either identify with the agitating groups, or have sympathy for the activities of the group. The Nigerian President behaves like the proverbial man whose house is on fire and he is busy chasing a rat. He continued to clamor for the recognition of self-determination of Palestine and the Southern Sahara by the UN but vehemently opposes any form of self-determination at home, forgetting that charity begins at home. In his address at the 70th Session of the United Nations General Assembly on September 28, 2015, President Muhammadu Buhari seriously supported the idea of self-determination by saying that,

as we continue to debate annually in this forum, let us always remind ourselves of the founding principles of the United Nations. These include selfdetermination and peaceful co-existence. In view of this, Mr. President, the unsettled problem of self-determination for the Palestinian people and those of Western Sahara, that have been adjudged by this Organization as being eligible for this indisputable right must now be guaranteed and ratified without any further delay or impediment. The international community has come to place its hopes on deciding the future of the Palestinian question through the two-state solution that recognizes the legitimate right of each state to exist in peace and security. The world has no more justifications or explanations to delay the enactment of the long list of Security Council Resolutions on this question. Neither do we have the ethical right to deny any people their sovereignty or condemn them indefinitely to occupation and blockade. ${ }^{66}$

In all, the Nigerian government should understand the changing trend in the fundamental human rights, and especially, the right to self-determination. They should realize that as a signatory to some of the treaties, statuses and covenants on human rights, these rights are now a universally acknowledged right that it is entitled to and available to all, especially those who are threatened with genocidal extermination. When these rights are not respected, even when they are enshrined into the constitution, it amounts to the violation of human rights. With this, agitations will continue in the country in various forms, and this will in turn threaten the development of the country and scare away investors and would-be investors.

\title{
64 Eastern Pilot p.5
}

65 Achebe, C. The Trouble with Nigeria ( Enugu: Fourth Dimension, 1983), p. 45

66 Muhammadu Buhari, President, Federal Republic of Nigeria at the 70th Session of the United Nations General Assembly, New York, 28th September, 2015, see Appendix 
Human Rights Violation: A Study of the Indigenous People of Biafra Agitation (IPOB)

\section{REFERENCES}

Achebe, C. The Trouble with Nigeria ( Enugu: Fourth Dimension, 1983)

Agbodo, Julius Amara Attah, and Patience Obi, "Biafra Day: IPOB Extends Sit-at-Home Order, ” Daily Sun, May 25, 2017

Agbu, Innocent ,The Origin of Biafra (Awka: Mercury Bright Press, 2001)

Akintunde, Mamedu 'Can the Centre Hold?' Africa Today, (6) 2: 2000

Amamkpa, A. and Mbakwe, P. "Conflict Early Warning Signs and Nigerian Government Response Dilemma:

Amuda Kannike "Agitation for Independent State of Biafra and its Implications under Domestic and International Human Rights Laws"

Brown, Michael and Margret Brown, "Are There Politico-Legal Differences between Self Determination and Secession: A Comparative Analysis on the Nigeria and Biafra Civil War 1967-1970" in International Journal of Public Policy and Administrative Studies, 11(4): January, 2018

Chapter VI of the 1999 Constitutional of the Federal Republic of Nigeria as amended.

Chijioke Kalu , Epele Biepi and Tamunosiki Dere (Oral Interview)

Constitution of the Federal Republic of Nigeria, 1999, as Amended.

Daily Sun, “Quit Order to Igbo: IGP Reads Riot Act," June 9, 2017

\section{Eastern Pilot}

Eke, Ugoji “IPOB Asks Members to Stay at Home on Remembrance Day,” The Nation, May 10, 2017 ,

Ekene Egbujule, and Onyinye Anyadike, "Nigeria fails to come to grips with separatist" New Biafra, 16 December 2016, https://www.refworld.org/docid/585a4f2c4.html Retrieved in October 2020.

Ekpo, C.E. and Agorye, C.A. "A (Un)Just and (Un)Holy War? The Theme of Imagery and Symbolism in the IPOB Secessionist Struggle" in International Journal in Management and Social Science Volume 6 Issue 06, June 2018

Ekpo, C.E. and Agorye, C.A. "A (Un)Just and (Un)Holy War?”

Emekesiri, Emeka Biafra or Nigerian Presidency: What do Igbos Want? 
JHSS, Vol. 11, No. 2, July to December, 2020

Godwin Tsa, Aloysius Attah, and Laide Raheem"IPOB Remins Terrorist Group”, Daily Sun, 26 September, 2017

https://www.google.com/search?q=meaning+of+fundamental+human+rights\&oq=meaning+of $+f$ undamental+human+rights\&aqs=chrome..69i57.9607j0j7\&sourceid=chrome\&ie=UTF-8, Retrieved in October, 2020

Idachaba, E.U. and Nneli, T.J. “Re-Invented Abroad: Agitation for Self-Determination

Ijalaye, 'Legal Implications of Nigerian Civil War', AJNH, 1969

International Crisis Group, Nigeria: The Indigenous People of Biafra (IPOB), including Objectives, Structure, Activities, Relations with other Biafran Independence Groups, and Treatment by Authorities (2014-October,2016) https://www.refworld.org/docid/5844003b4.html Retrieved in October 2020.

Isaac Adaka-Boro And the Niger Delta Militancy, http://www.niaraland.com/nigeria/topic302497.0html Retrieved Ocober, 2020

Isiaka, Badmus "Ethnic Militia Movements and the Crisis of Political Order in Post-Military Nigeria"

Kanu, Chidindu Chinweike Okoro, Jude Njoku and Calistus Elemuo (Oral Interview)

Kevin, Ifeanyi "Ethnic Militancy in Nigeria: A Case Study of MASSOB, 1999-2010," Unpublished M.A. Thesis, 2011

Muhammadu Buhari, President, Federal Republic of Nigeria at the 70th Session of the United Nations General Assembly, New York, 28th September, 2015.

Nwabueze, B. A. Constitutionalism

Obi-Ani, Paul , Post-Civil War Political and Economic Reconstruction of Igboland, 1970-1983 (Nsukka: Great AP Express Publishers Ltd, 2009)

Ogan, Agbu, "Ethnic Militias and the Threat to Democracy in Post-Transition Nigeria" News from the Nordic African Institute, Upsala, Sweden. N0.1; January, 2002, Retrieved October, 2020

Oji, Charles “Biafra Agitators Kick Against Igbo Leaders Decision” The Nation, July 3, 2017

Ojibara, Innocent "Biafra: Why Igbo Want to Secede" in Arabian Journal of Business and Management Review (Nigerian Chapter) Vol. 4, No. 1, 2016

Ojo, Samuel and Monday Kilete, "North Declares War on Igbo", Daily Sun, July 7, 2017 
Human Rights Violation: A Study of the Indigenous People of Biafra Agitation (IPOB)

Ojo, Samuel Timothy Olanrewaju, Godwin Onyjiuwa, and Chinedu Obogo "Quit Order: Igbo Spit Fire,"

Ojo, Sola Timothy Olanrewaju, Gorge Onyejiuwa and Chinelo Obogo,"Quit Notice Order to Igbo: IGP Reads Riot Acts”, Daily Sun, June 9, 2017

Okonkwo, Thompson and Godwin Kingston "An Assessment of the Rights of the IPOB to Selfdetermination under International Law”, Sacha Journal of Human Rights, Vol. 16(1), 2016

Olaniyi Oladejo, 'The Illusion of Revolutionary Idealism', The Guardian, Thursday October 17, 1991

Oloyede, Oyedele "Biafra in the Present: Trauma of a Loss" African Sociological Review/Revue Africaine de Sociologie, 13(1), 2009

Onimajesin, Shola "The OPC Militancy in Nigeria, 1999-2003: Its Implications and Management." http://www.unilorin.edu.ng/unilorin/publications/onimajesin.html Retrieved October, 2020.

Onu, Naomi Calistus Oji, Chinelo, and Samuel Nwankwo, "Biafra Day Grounds Imo, Enugu, Anambra and Abia", The Nation, May 31, 2017

Onwuka Njoku (Ed) Topics in Igbo Economic History, Ikeja: 1st Academic Publishers, 2008

Opata, Christian "Radical Ethnic Organizations and the Sustenance of Democracy: The Case of $M A S S O B$ " in Juluis Onuoha and Paul Okpoko (eds) Ethnic Nationalism and Democratic Consolidation: Perspectives from Nigeria and the United States of America (Nsukka: Great AP Express Publishers Ltd., 2004)

Opejobi, Salihu "Biafra: IPOB Denies Taking up Arms Against Security Agencies in Selfdefence,” Daily Post, 2017. http://dailypost.ng/2016/02/17/biafra-ipob-deniestaking-up-armsagainst-security-agencies-in-self-defence/ Retrieved in October 2020.

Osadolor, Ben "The Development of the Federal Idea and Federal Framework, 1914-1960"

Sun Reporters, “Biafra: South-East Shuts Down”, Daily Sun

Tamuno, Tekena "Nigerian Federalism in Historical Perspective" in Kenneth. Amuno (ed) Federalism and Political Restructuring in Nigeria, (Ibadan: Spectrum Books Ltd., 1998)

The Alaigbo Development Foundation (ADF) CONDEMNS.46.

The Unrepresented Nations and Peoples Organization (UNPO) Retrieved in October 2020.

Thomson and Godwin "An Assessment of IPOB” 
JHSS, Vol. 11, No. 2, July to December, 2020

Wolfgang, D. Anne-Marie Gardner https://pesd.princeton.edu/ Retrieved in October 2020 